\title{
Three Trips in One Plane: Martial Arts and Combat Sports Conferences in Muju, Osaka, and St. Petersburg
}

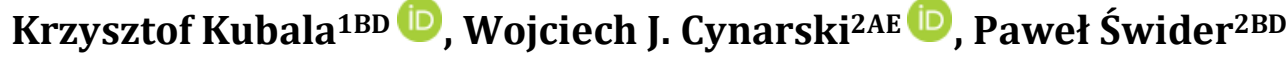 \\ 1 International Martial Arts and Combat Sports Scientific Society (IMACSSS) Rzeszow \\ 2 Faculty of Physical Education, University of Rzeszow (Poland)
}

Authors' Contribution: A - Study Design, B - Data Collection, C - Statistical Analysis, D - Manuscript Preparation, E - Funds Collection

\begin{abstract}
Problem and Aim: The current article is an attempt to summarize the experiences gained from two foreign conferences, the 50 th Japanese Academy of Budo Conference and the $2^{\text {nd }}$ International Budo Conference at the Centenary Memorial Hall on Kansai University, which were recognized simultaneously as the VI International IMACSSS Conference, and the accompanying events, as well as $8^{\text {th }}$ International Scientific Congress "Sport, People and Health", organized by, among others, P.F. Lesgaft National State University of Physical Education, Sport and Health and the International Sambo Federation. The third of these scientific events was the $6^{\text {th }}$ International Taekwondo Symposium for Taekwondo Studies, which was held in Muju, South Korea. Materials and Method: Due to the multidisciplinary approach nature of the conferences, content analysis of literature and extensive discourse analysis as well as the participant observation were used. Three case studies are also provided. Results and Conclusions: The indicated trips and scientific events offal within martial arts tourism, which is at the same time a journey for scientific study and exchange of knowledge related to martial arts research. It is therefore connected with scientific tourism as well as with congress and educational tourism. The described scientific events are relevant for research on martial arts tourism and for describing the process of institutionalizing the scientific research of martial arts and the recent history of the institutions in this area.
\end{abstract}

Keywords: martial arts, combat sports, scientific conferences, martial arts tourism, participant observation

Address for correspondence: Paweł Świder - Faculty of Physical Education, University of Rzeszow, Poland, email: pol1977@op.pl;

Recevied: 24.07.2018; Accepted: 19.01.2019; Published online: 19.06.2019

Cite this article as: Kubala K, Cynarski W, Swider P. Three Trips in One Plane: Martial Arts and Combat Sports Conferences in Muju, Osaka, and St. Petersburg. Physical Activity Review 2019; 7: 114-124. doi: 10.16926/par.2019.07.14 


\section{INTRODUCTION}

Travels to distant, exotic places or to those that used to be easily accessible to us and were connected with our universities by numerous scientific cooperation agreements, and now have become for us again exotic and distant for visa and political reasons, bring us new knowledge and are an opportunity to experience, on which we build not only scientific information, drawn from conferences and congresses, but also the possibility of comparison and generalizations, concerning the tradition and culture of places visited within the framework of 'martial arts tourism'. Contact with colleagues at such events and the possibility of meeting new people are also important, which can instigate the decision to hold further conferences in new university centres, which have not yet been used for scientific meetings, and which are interesting due to the dynamic development of research in the field of sports and martial arts, in order to discover new places on the map for themselves, which have not yet been recognized in this respect. Unfortunately, during the three scientific events discussed here, the problems of 'martial arts tourism' and 'martial arts sociology' were still only marginally present and did not constitute an independent trend. However, it was possible to find several memorable texts, indirectly connected with its subject matter, or accompanying conferences and the congresses with practical demonstrations and study tours, which, due to their connection with martial arts, were the cause of this tourism and the starting point for further generalizations and reflections, including sociological ones.

The problem of the subject matter and the more precise definition of 'martial arts tourism' has appeared relatively recently [1-3] and is developed on the basis of the sociology of martial arts and the General Theory of Fighting Arts [4]. This relatively new subdiscipline of knowledge is only now taking its first steps in Polish and world literature, although it is undoubtedly as old as the martial arts itself, as traveling to get to know and improve skills under the guidance of great martial arts masters in Japan, Korea, and other countries of the Far East has a huge tradition. They are also present in the journeys of martial arts instructors and their students, undertaken in order to teach their skills and the related phenomenon of expansion of the arts and sports of fighting from their places of origin to new places. This phenomenon can also be called cultural expansion, because in new centres cultivating traditional martial arts (i.e., dojo; Japanese for martial arts training halls), masters and students adopted traditional terminology and names, as well as a certain philosophy related to their lifestyle and knowledge derived from their homeland.

It also seems to us that there is a deeper justification for the analogy with philosophy, since the beginnings of Greek philosophy are connected with traveling teachers-mayors, who wandered from place to place in search of students, and then abandoned the journey and settled permanently establishing their own schools, to which students who were attracted to the fame of the teacher had to make pilgrimages. This migration of students was important not only for the students but also for the formation of the Hellenistic cultural unity and pride of belonging to this culture (from which, through Rome, the formation of Christianity, the whole of European and Atlantic culture was born, an influence that continues to impact the present world community significantly).

A similar evolution has taken place from itinerant teachers looking for students to the famous martial arts instructors who moved on to stationary learning sites they create. This analogy has an additional spiritual aspect. Traveling Greek teachers and martial arts instructors both conveyed a holistic picture of the world, its perceptions and standards of conduct, in accordance with the system they had created. That is why the Shaolin Temple became legendary for martial arts, and why at Plato's Academy, where after 25 years of teaching, according to Plato's concept, warriors left the school, and only after the next such period, wise kings did the same. Similarly, in Japan, great masters have made significant contributions to the agonist culture and samurai code (bushido), which has long been a significant part of Japanese culture and the values cultivated in that country [5].

In today's world, thanks to globalization and ease of changing the place of residence as well as global pop culture, knowledge about martial arts and sports originating from the Far East has become so popular that one does not even have to travel to Asia, because the possibility of studying these systems of knowledge exists in almost every country of the world. Additionally, many schools referring to their own traditions have been created under influence of Asian traditions. Some often have a 
strictly utilitarian character (e.g., Krav Maga) and are devoid of the mystical and cultural layer that the Japanese and some other nations of the Far East have given to their martial arts.

That is why martial arts students, fascinated with the culture of the Far East, often travel in search of spirituality to its roots and study in Asia. They often remain permanently, becoming teachers themselves and accepting them as their own local culture, growing into it through marriage and university work. Some of students treat this part of their lives as an initial stage and, after returning to their country, establish their own martial arts school or start working in the existing ones. For those who feel connected to the martial arts, there is an opportunity to get to know the world of martial arts during sports events and scientific conferences devoted to this field. Participation in such events also requires travel and is highly specialized.

As active members of International Martial Arts and Combat Sports Scientific Society (IMACSSS) [6], who study art and combat sports holistically, we have often travelled to many countries around the world where scientific conferences have been organized, often being the organizers or coorganizers of such events [7-9]. As in the case of one of the congresses in Japan discussed herein, it was possiblity to meet here naturalised graduates of Japanese universities. The aims of these trips were to get to know the current state of knowledge in the field of martial arts and sports research, to meet colleagues from other conferences, and to meet new researchers. Through these conferences, we had hoped to share our views with them and to encourage them to cooperate further within our organization - IMACSSS or others, such as International Society for Social Sciences of Sport (ISSSS), Japanese Academy of Budo (JAB), or International Association for Taekwondo Research (IATR).

This standard goal of all scientific conferences in our case is was supplemented by important for researchers, combining theory with practice. That were demonstrations of the efficiency of the above mentioned various martial arts schools, and then the achievements and specificity of training in well-known martial arts varieties, cultivated locally. These conferences also permitted us to witness demonstrations and lessons of the greatest martial arts instructors of a given region or meet outstanding "stars" in our academic disciplines. But there is another very important issue, namely to be in the places where these or other schools were born or where eminent senses worked, or to meet first-hand the creators of new martial arts schools or the individuals who gave rise to a completely new approach to the discipline or whom created the rules that we apply in our fields is an invaluable learning experience. Traveling to such special places is unique, because we meet likeminded individuals in unique places and connect with the traditions we consider to be our own and with which we identify ourselves. Thanks to this, we can later cultivate with even greater dedication the research of martial arts and deal with their cultivation.

There is an analogy here with religious pilgrimages or visits to places of national glory made by believers and patriotic citizens in order to touch the places where their prophets and national heroes lived and won. Visiting places with which we feel exceptionally connected by emotions, imagination and our own way of life, we make a kind of "quasi-sentimental pilgrimage," because we have a kind of spiritual experience, important for our psyche and strengthening the motivation of dealing with martial arts and combat sports. Later, we can deal with these experiences professionally. Several of these journeys give the traveller a sense of transitioning to a higher level of initiation and commitment to the issues that are the subject of their passion. The Greek Olympians probably felt the same thing during the Olympic Games, which were held in honour of their gods and were also agonist in character. This religious side of the modern Olympic Games has been lost, as has the cultural side that Baron de Coubertin attempted to introduce into the Games by introducing gold medals for literary, musical, and artistic works to recognize and reward writers, poets, painters, sculptors, and composers on an equal footing with athletes.

Hence, martial arts-related travel is unique and exclusive in nature, demonstrating a new need which, in the case of martial arts practitioners, cannot be reduced to simple research into the sociology of tourism (and recreation), which has developed so widely and rapidly in recent years as a result of rising incomes and globalization. The links between 'martial arts tourism' and cognitive, sporting, and extreme tourism and religious tourism are linked to the fact that journeys of this nature are undertaken by special individuals who are spiritually and professionally linked to martial arts and combat sports., a very small group in number that, by virtue of their activity, are exclusive and highly integrated internally. It is imperative for such tourists to make maximum use of each trip to achieve all 
the above-mentioned objectives, as far as the means and circumstances allow. Knowledge and exchange of experience, practice and observation of the best practitioners and masters, group integration in a professional circle, and spiritual experiences connected with one's passion and combined with observations of the culture that created the martial art studied are the tasks that are usually faced by a martial arts or combat sports traveller. As the popularity of this field is growing rapidly, it can be assumed that the number of researchers-practitioners as well as martial arts enthusiasts will grow exponentially to create a new kind of tourism in the world and a new scientific sub-discipline that studies the phenomenon of 'martial arts tourism' sociologically. Therefore, this emerging science is on the border of the sociology of martial arts and martial arts tourism.

As such, it has every chance to explore new, yet unexplored research topics and thus achieve extremely interesting results. The current article is an attempt to summarize the experiences gained from three foreign conferences on martial arts and combat sports within this hitherto now unexplored perspective. It is a contribution to knowledge about this type of tourism. The authors search for information on the characteristics that differentiate or are common to different varieties of martial arts tourism according to the destination country. The hypothesis is - each destination requires a separate qualitative analysis.Due to our multidisciplinary approach, a content analysis of the available literature, extensive discourse analysis, and a participant observation were used [10]. We can speak on a study of three cases (three specialist conferences) [11,12]. The literature of the subject was searched according to the Web of Science, Scopus, and Mendeley databases. In addition, popularscientific magazines such as "Gazeta Uniwersytecka Uniwersytetu Rzeszowskiego" (2010-2017), "Forum Akademickie," and some other materials (e.g., photos) were included.

\section{The 50th Japanese Academy of Budo Conference \& $2^{\text {nd }}$ International Budo Conference \& IMACSSS Symposium}

On September 6-8, 2017 the JAB, Japan's largest organization of university teachers and practitioners of traditional Japanese martial arts, convened its $50^{\text {th }}$ jubilee called theAcademy of Budo Conference in Osaka, Kansai University, which is also the $2^{\text {nd }}$ International Budo Conference and the $6^{\text {th }}$ International IMACSSS Conference. The place was at the Centenary Memorial Hall on Kansai University. Again, Prof. Dr. Wojciech J. Cynarski was a special guest of the JAB, who was the only Pole invited to chair one of the plenary sessions of the conferences. The long-standing scientific cooperation between $\mathrm{JAB}$ and IMACSSS has thus once again been symbolically rewarded.

During the opening of the conference, Professor Fuminori Nakiri, JAB President, expressed his satisfaction that the cooperation of scientists studying the problems of budo (Japanese martial arts) and martial arts in general has taken on a global character. According to Professor Nakiri, the conference has become more representative thanks to the cooperation with many foreign organizations, among which he mentioned in the first place IMACSSS, which was founded in Rzeszów, Poland at the International Martial Arts and Sciences (Lancashire, UK). In addition to the Japanese part of the Budo Conference, an International Symposium Budo and Martial Arts: Crossover of Traditional Culture and Popular Culture was held at the same time, to which Professor Nakiri invited Professor Wojciech Jan Cynarski, IMACSSS President, as the keynote speaker and chairman of the International Session Panel-. In this session, Professor Cynarski presented his paper "Budo in Global Culture: From the Traditional to the Popular." More than 300 participants attended the conference, including guests from Europe and the Americas, the vast majority of whom were members of IMACSSS.

The subject of the influence of mass culture on Japanese tradition and at the same time the influence of the Japanese tradition symbolized by Budo on the global mass culture is-interesting here and is connected not only with cinematography, in which the Japanese initiated a new genre of "martial arts cinema", later developed throughout Asia (such as the 1925 silent film Orochi). The face of this cinema became Bruce Lee, a Chinese-American martial artist and film star, thanks to which it became a part of the global mass culture. It is also Japanese art -manga, more and more popular all over the world in its various forms, and Japanese minimalist aesthetics, derived from tradition. All of this, and not only this, was discussed at the conference. The central lecture of the first day in this field was a speech by retired professor Yamaori Tetsuo entitled "The Sword and the Gun at the International Research Centre for Japanese Studies," where he discussed the combination of Bushido 
(samurai code) and a modern firearms-based army in which the Japanese try to preserve as much of their old traditions and ethos as much as possible.

On the first day of the evening, during a ceremonial banquet, Japanese hosts also presented honorary diplomas for distinguished foreign guests. Professor Nakiri was the first JAB President to honour Professor Cynarski. In addition, Abel Figueiredo, Carlos Gutierrez-Garcia, and Michal Vit, all members of the IMACSSS Management Board, were also awarded prizes. Professor Nakiri was also awarded by IMACSSS a honorary diploma in recognition for his long-term cooperation and services to IMACSSS, which was presented to him by President IMACSSS, Professor Cynarski.

The meetings were also held in the Humanities, Natural Sciences, Budo Instruction, International and Postal Sections. The deliberations of one international section were simultaneously qualified as the VI Scientific Conference of our IMACSSS Association. During the break of this section, the IMACSSS Management Board met to discuss the problems related to the organization of the Fourth World Congress of Combat and Combat Sports, organized at the Faculty of Fine Arts at the University of Rzeszów, which was eventually held in in Rzeszów, Poland in October, 2018.

The conference was efficiently conducted by the organizers, who have a half century of experience of conducting academic events. The diversity of debates and additional attractions were provided in the form of demonstrations of various martial arts practices. The conference included Judo, Kendo, Karate-do, Kyudo, and Naginata-all Japanese martial arts-workshops, which demonstrated the traditional skills of hosts in their fields. Another workshop on Budo for the Disabled demonstrated how individuals with physical and intellectual disabilities can benefit, to the extent of their abilities, from martial arts practice. At the end of the session of the Academy of Budo we invited everyone present to the $7^{\text {th }}$ International Scientific Conference IMACSSS and the $4^{\text {th }}$ World Congress of Combat Sports and Martial Arts [7,8,13].

In Japan, we travelled by train from an impressive airport, and a few neighbouring small towns that belonged to the agglomeration. However, the journey took place in the evening and the observations were at most impressive; on the way back in the late afternoon, the departure allowed for a few more observations, which were very impressive because of the huge scale of the construction and industrial areas and the harbour the train was passing through.

During the Kansai University Conference on Martial Sports Tourism, it was worth noting the texts that discussed the subject. The first of them was a paper by Amanda Spenn from the University of Wolverhampton (Wolverhampton, England) entitled "Sarah Mayer: A Judo Journey." In this research the author presented an interesting figure of Sarah Mayer, who came to Japan in 1933 to study Judo with Jigoro Kano and achieved significant results in this field. She was the only woman found physically capable of training in the main dojo (martial arts practice hall) with the men. She had the honour of being taught at the Kōdōkan, the Judo world headquarters, by such masters as Mifune Kyuzo and Nagaoka Shuichi, and she partnered with Samura Kaichiro as part of the demonstrations of Judo's $50^{\text {th }}$ anniversary celebrations, despite having a dislocated shoulder injury. She was the only western participant at the event, and her exploits were widely publicized in Japan through Japanese and English language journals and newspapers all over the world" [14]. She can be considered an icon of female and feminist movement thanks to the popularization of Judo throughout pre-war Europe, where she conducted lessons with outstanding Japanese instructors and thereby attracted many European women to the martial art. It was recognized as a global phenomenon of ,"Modern Girl” in the 20 s of the 20th century. Her travels to Japan and subsequent European tours were a kind of popularization and tourism that were connected with combat sports.

The second lecture worth mentioning here was "Current Status and Issues of the Kōdōkan Jūdō Museum" by Kiryu Shusaku. The author is a collaborator of the museum and wrote that the initially modest collection, consisting of memorabilia of Jigoro Kano, was transformed into a museum in 1894 and is now an important part of the institute Kōdōkan. The number of visitors is still growing and is expected to peak at the Olympic Games in Tokyo in 2020 [14]. 


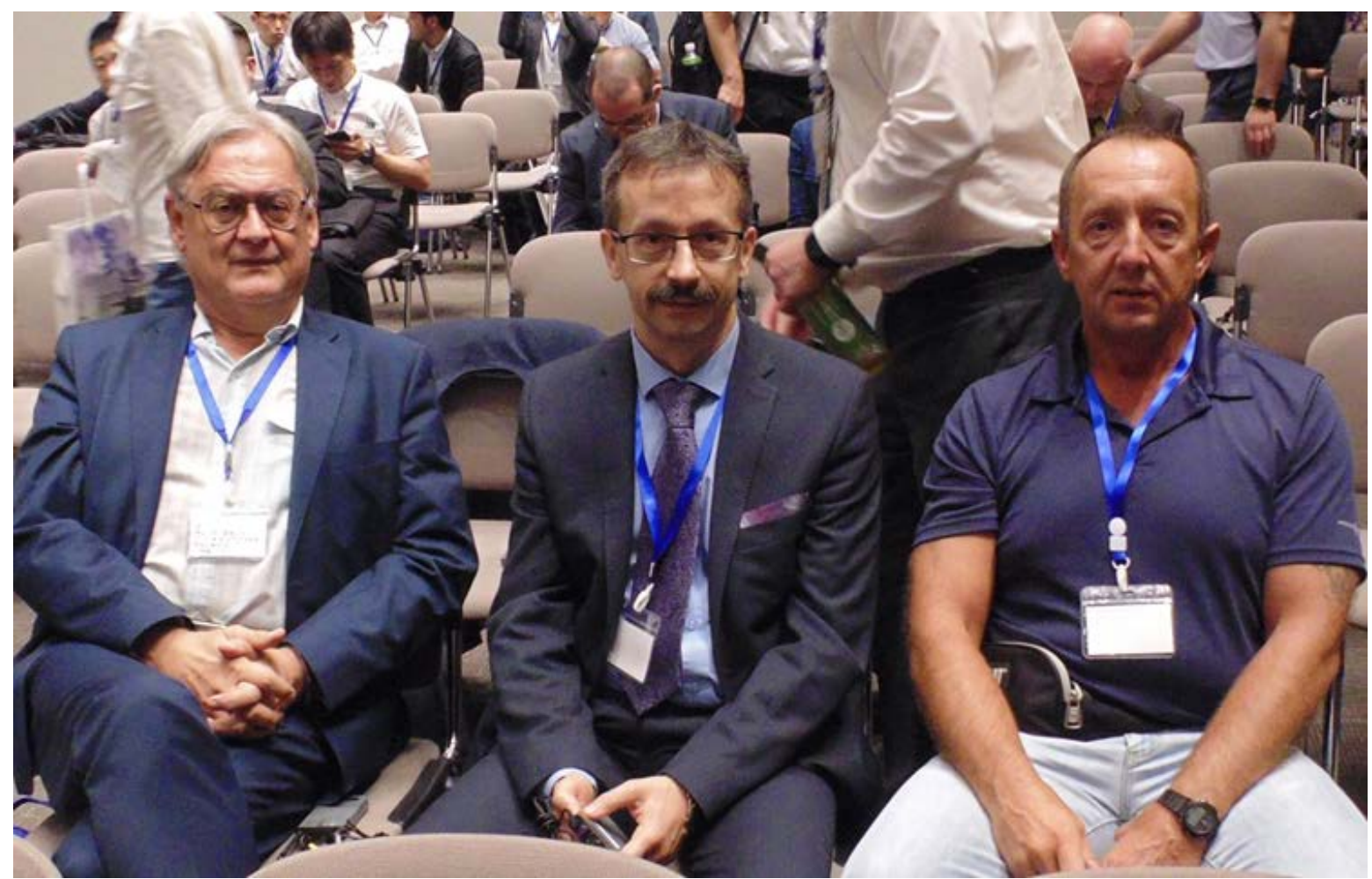

Figure 1. From right: Professor A. Brito, Professor W.J. Cynarski, and Dr. K. Kubala at Aula Kansai University (author's own collection).

\section{The $8^{\text {th }}$ International Scientific Congress "Sport, Man and Health" in St. Petersburg, Russia}

Previously, scientific cooperation between socialist countries was supported by the authorities (representatives of power) and universities often signed scientific agreements and allocated funds for such cooperation. The lack of convertible currencies and the Iron Curtain were major obstacles to this kind of scientific contact with Western countries. If there was joint research, it was only possible at the invitation and expense of the Western academics. Today, this situation is a thing of the past, although from the point of view of researchers the funding of science still leaves a lot to be desired.

The changes that have taken place in Russian and around the world as well as the impact of globalization allow us to express hope that scientific contacts, despite differences in perception, which have been interrupted for many years due to the crisis, will continue. The idea to invite our delegation came from the Russian side and resulted from the appreciation of the importance of IMACSSS and its president's personnel in the global scientific research movement of sports and martial arts, in which the Russians also have their achievements and their own combat sports, namely Sambo. An additional, subjective aspect of the development of sports and martial arts and their scientific research in Russia is the well-known fact that Vladimir Putin, the Russian president, is a Judo practitioner and is often shown in the media at the mat during competitions under his patronage and show fights to show his efficiency and power to create a propaganda "image fighter" for Russians and the rest of the world. Although strong today, Russian interest in martial arts and sports In view of the image problems of Russian sport, scientific research on martial arts and combat sports is something neutral and, at the same time, one of the gates that opens up opportunities for scientific cooperation for Russians today, regardless of potential differing political views between Russian academics and their international counterparts.

Therefore, our trip to the the $8^{\text {th }}$ International Scientific Congress "Sport, Man and Health" in St. Petersburg, Russia, which was held from October 12-14, 2017, can be regarded as a kind of bridgebuilding, a kind of attempt at renewing the old cooperation. Other foreign delegations represented some countries that were former Soviet Bloc republics and once friends of the "Third World." In the media information, Poland was shown as one of the participants. Interest in our presence was also 
expressed by journalists of the Polish newspaper, published on the Internet, who reported on the course of the congress.

In connection with the Congress, we did not have much time to get to know the Russian culture or people, but we took the opportunity to visit the Hermitage, provided by the Congress Organizing Office, and a short trip to the city centre, undertaken on our own. In addition, the hosts presented the participants of the congress with the opportunity to visit the sports facilities and take part in training and shows of fighting arts However, the date of the congress was not favourable for tourism, because the St. Petersburg is located on the border of the Arctic Circle near the sea, and therefore had a cold, damp and shortened day in October. Hence, the time of year limited sightseeing opportunities by the organizers.

Also in the congress theme, "Sport, People and Health," the leading topics were related to Olympic sports and World Movement activities "Sport for All" and traditional for researchers working at the universities of sports and universities of physical education, research topics in the field of the Theory of Sports Training, the sports preparation of students and players and medical, methodical and psychological support for athletes. For most of the 'martial arts' and non-Olympic combat sports there was little room for - perhaps apart from the already mentioned Sambo and military preparations for hand-to-hand combat, present in several papers by representatives of officer schools The participation of the congress participants in the demonstrations of sambist skills was so important for the organizers of the Congress; however, it was placed among the performances of other athletes in the shows inaugurating the Congress.

The only possibility to learn more about the organization of training and the infrastructure of 'combat sports' was an optional trip concerning the civil youth sports clubs in the city.

This rather superficial and eager to explore further Russian martial arts may in time be complemented by further information if the issue of our scientific contacts and cooperation with Russian organisations and universities is improved. We hope that this will be possible in the foreseeable future.

Finally, a few words about the hotel where the Conference Centre was held. It was built by the Finns for the Moscow Olympics as the "Gostinica Pribaltijskaja" ("Baltic Sea Hotel") and was intended for Western guests. It was an oasis of luxury in the former USSR, and few Russians had access to it. Today, after much renovation, it belongs to the Park Inn hotel chain and although the interiors have not changed much, in comparison with other new housing estates and hotel buildings, it has become a terraced hotel and is used mainly for accommodation for organized tourist groups from China, which we had the opportunity to observe during the stay. What used to be an exceptional luxury has now been overtaken by the average. The hotel is also no longer located by the sea, because the areas recovered from the sea have been used to build a toll motorway in diameter and new, exclusive housing estates are being built, so its silhouette has ceased to be a part of the sea panorama of the city.

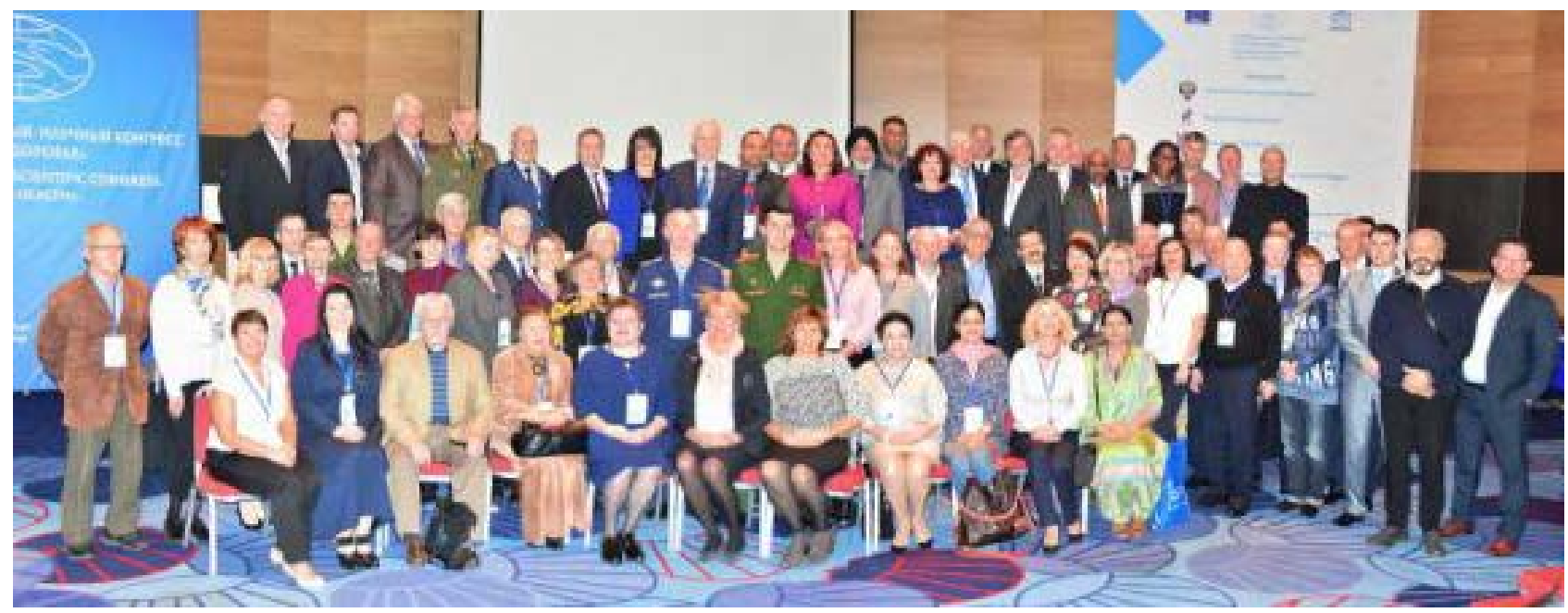

Figure 2. Participants of the $8^{\text {th }}$ International Scientific Congress "Sport, Man and Health" in St. Petersburg, Russia in 2017 (authors own collection). 


\section{The $6^{\text {th }}$ International Symposium for Taekwondo Studies}

The third of the discussed conferences took place from 29 to 30 July, 2017 and was $6^{\text {th }}$ International Taekwondo Symposium for Taekwondo Studies, which was attended by employees of the Faculty of Physical Education of the University of Rzeszów, Professor Wojciech J. Cynarski and Dr. Paweł Świder [15]. The aim of the Taekwondo International Symposium was to present the current state and development prospects of this field of martial arts, both in the philosophical and historical, as well as psychological and medical aspects. The organisers of the scientific event were the International Association for Taekwondo Research (IATR) and the World Taekwondo Federation (WTF; the international federation for Olympic Taekwondo), organizations that promote respectfully this martial art academically and competitively. The conference took place in Muju, South Korea.

Since this martial art is the national sport of Korea, the symposium was honoured by representatives of the highest local authorities. At the same time the conference was correlated with the WTF World Championships, which is why one of the speakers was the President of the International Olympic Committee (IOC) Dr. Thomas Bach. During his speech, he stressed the important role of this sport, not only in Korea, where it had its origins, but also worldwide. Of course, important in his speech were not only analogies to its sporting aspects, but also to its philosophical concept as a martial art.

The symposium was attended by representatives from all over the world, including Argentina, Australia, Belgium, China, Switzerland, Taiwan, Turkey, Iran, Korea, Brazil, the United States, Poland, Canada, Germany, Japan, Great Britain, and Russia. This demonstrates the popularity of Taekwondo and its global impact on sports in historical, philosophical, marketing, psychological, and medical terms. There were more than 100 academic presenters at the symposium. The fact that presenters came from Christian, Islam, Buddhist, Confucian societies and other religious and social systems highlights the diversity that Taekwondo and other martial arts and combat sports can bring together.

As the conference was multi-disciplinary in nature, it was divided into two thematic section: the social sciences (Philosophy, History, Management, and Marketing) and natural sciences (Psychology, Nutrition, and Medicine). There was also a multi-disciplinary poster session. In the first panel, the speeches focused mainly on the historical development of the discipline in individual countries, organisational structures, and training elements. The second panel was also multidisciplinary and included not only the mentioned issues of Psychology, Nutrition, and Medicine in Taekwondo, but also the problems of its globalization and correlation with other sports and recreational disciplines, such as aerobics and fitness.

This trip not only allowed for an exchange of views with representatives of this scientific discipline, but also allowed for conducted surveys on the tourism of martial arts and get to know local traditions and culture. During the observation, Taekwondo won Park in Muju was visited as a martial arts and sports facility. The complex was opened in 2009 and houses the Taekwondo Academy, its base: Arena, Museum, Theatre and Experience Centre Yap. In addition, the territory includes the Narae Hall (Multicultural Hall); a large auditorium; small and large lecture halls; discussion rooms; small, medium, and large indoor and outdoor Taekwondo training facilities, a football (soccer) field; hiking paths; small grass fields; and the T1 Stadium.

The Taekwondo won, under the auspices of the Ministry of Culture, Sports and Tourism, offers more than 45 types of training programs for applicants from Korea and around the world. The programs are suitable for all those who are interested in Taekwondo, including practitioners, business groups, students, and the general public. It can be said that it is a fully prepared tourist and sports facility for martial artists and athletes, with the additional possibility of organizing trips to Taekwondo centres throughout Korea.

The trip, as mentioned, was correlated with the Taekwondo World Championships, which, in addition to excellent organization and visual setting, allowed us to state that South Koreans still feel a common identity with North Koreans because everywhere flags and banners were displayed calling for reunification into a single state entity. 

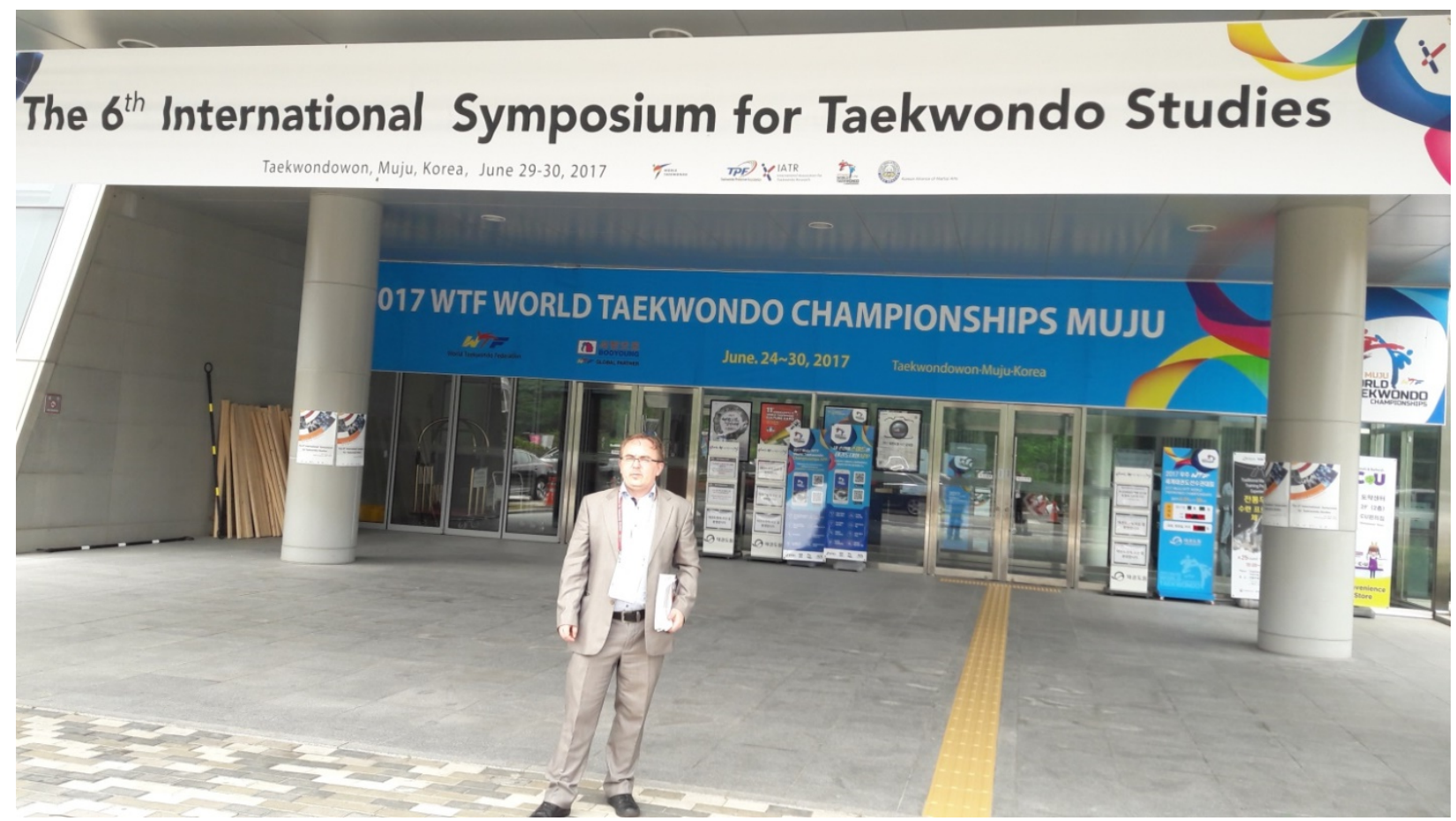

Figure 3. Dr. Paweł Świder at the 6th International Taekwondo Symposium for Taekwondo Studies in Muju, South Korea (authors own collection).

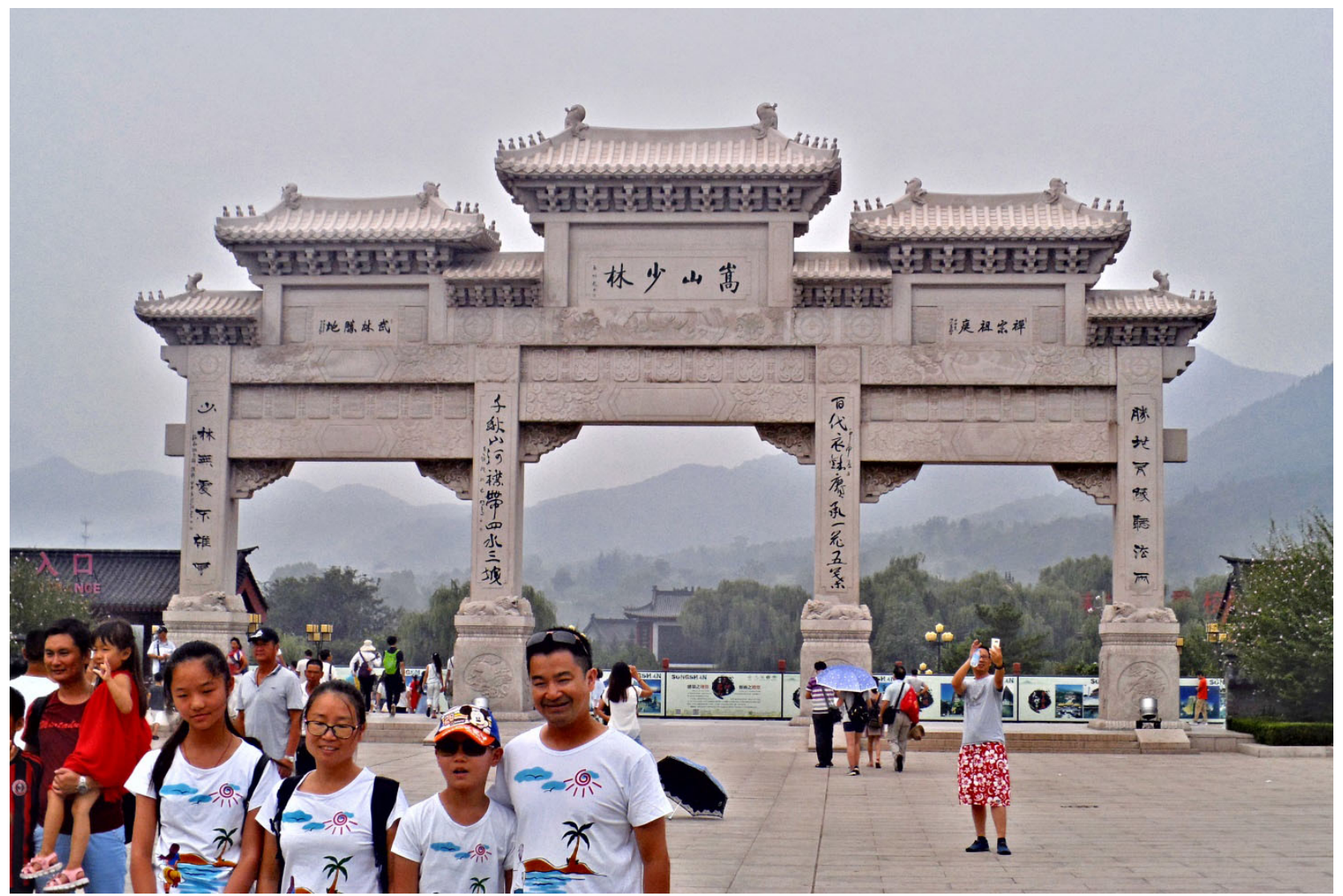

Figure 4. Gateway to the Shaolin Monastery, Henan Sheng, China (authors own collection).

In the case of passport and visa documentation (i.e., visas and other formal and legal documents) necessary for the trip, each Asian region is characterized by its own specificity. It can be said that in this respect it was easy to get to South Korea, because Polish and Lithuanian citizens do not need visas to enter the Republic of Korea for stays not exceeding 90 days under the visa waiver 
agreement. The only condition is that during their visit to Korea visa holders do not receive any money other than per diems to cover meals, accommodation, and air tickets.

In terms of the specificity of transportation, hotel and other services, Korean tourist agencies did not differ from European standards and are the result of the rapid economic development of Korea.

\section{DISCUSSION}

Martial arts tourism has a multidimensional character. Sometimes it is close to cultural tourism par excellence, as in the case of trips to Shaolin Temple [3,15-18]. Sometimes it is a trip to sources, not necessarily Asian (e.g., Brazilian Capoeira), which gives it a para-pilgrimage character $[1,19]$. Sometimes it is a long and expensive journey to learn and practice martial arts, for example from Europe to China [20]. In other cases, distillation is close because a master-teacher runs a school in Europe, for example, or an international training seminar is held relatively close to the practitioner's home under the direction of eminent instructors [2,21].

Some meetings of martial arts practitioners are of a mixed nature, the scientific-research, conference, and practical trainings (methodological and training) mentioned previously. They take place in permanent centres or in places with special tourist attractions [22]. Other times they are a form of sports tourism for players, activists, and support teams, such as a trip to an international tournament. In the case of a trip to Muju and the scientific event described above, the programme also included support for the WTF Taekwondo 2017 World Championships.

In general, however, the events discussed and reviewed above were scientific conferences. Therefore, these events are specific for both martial arts tourism and scientific tourism [8,22]. The novelty of the current study is therefore a multifaceted look, analysis, and comparison of three martial arts academic events, and contribution to the knowledge of this specific tourist phenomenon.

\section{CONCLUSIONS}

The indicated trips and scientific events belong to the form of martial arts tourism, which is at the same time a journey for scientific study and exchange of knowledge about martial arts. It is therefore connected with scientific tourism as well as with academic and educational tourism. The described scientific events are important for the martial arts tourism, but also for the fact that the process of institutionalizing the scientific research of martial arts and the recent history of the institutions in this area are important (for historical knowledge). The authors believe that the hypothesis was confirmed and the applied method of study of three cases was the best here. The specifics of each of the described conferences were presented as scientific events thematically related to fighting arts.

The stay at the these three events played a positive role in the exchange of opinions between the participants, getting to know new research areas of colleagues, the integration of the environment, and making new professional acquaintances. Moreover, it allowed us to familiarize ourselves with or broaden our knowledge of the culture of the countries in which we visited and, in some cases, to visit "very special " places, connected with "martial arts" or characters connected with this field, but also "ordinary" tourist attractions in the visited countries, which the hosts wanted to highlight. Of course, for us the most interesting part of the tourist program were places connected with the history of martial arts and the people who created and developed them.

The increased knowledge resulting from these expeditions will make it possible to deepen the information on people and places in the future. It will also improve participants' knowledge of their fields and what new fields of research can be explored. Other issues are places where martial arts have become a part of mass culture and attract millions of people annually (e.g., the Shaolin Temple) not interested in martial arts, but rather in martial arts cinema and e.g. Bruce Lee created as a "superstar" of this genre of cinema and consistently "monetized” after death on a large scale. Of course, martial arts tourists can also go there, but they should prepare carefully to avoid the dysfunctions of tourism that arise in these kinds of "Disneyland's" of mass tourism. Professional preparation gives the possibility of even more adequate tests and guarantees interesting research results. Furthermore, 
participation in study and reporting trips (Figures 1-8) provides the basis for experience and organizational skills that should bring the expected results.

\section{REFERENCES}

1. Cynarski WJ, Obodynski K. Wyjazdy do źródeł budo / Trips to budo sources. In: Bergier J, Żbikowski J, editors. Turystyka a religia / Tourism and Religion. Biała Podlaska: PWSZ; 2003: 333-338

2. Cynarski WJ, Sieber L. Turysta - wojownik. Mistrz sztuk walki podejmujący wyprawy samorealizacyjne / Tourist - warrior. Master of martial arts undertaking self-realization expeditions. Turystyka i Rekreacja 2006; 2: 45-51

3. Miller L. Martial Arts in Tourism. In: Green TA, Svinth JR, editors. Martial Arts in Global Perspective. Santa Barbara: ABC-CLIO; 2010: 411-416

4. Cynarski WJ. Towards a General Theory of Fighting Arts. Phys Activ Rev 2017; 5: 83-90.

5. Bennett A. Bushido and the Art of Living: An Inquiry into Samurai Values. 2017. Japan Publishing Industry Foundation for Culture

6. Kubala K. Genesis, the creation and development of International Martial Arts and Combat Sports Scientifics Society (IMACSSS), as a community of scientists and practitioners of Martial Arts and Combat Sports. Research Journal of Budo 2013; 46

7. Kubala K. Budo - to nie tylko sztuki walki, to japońska tradycja kulturowa i filozofia życia / Budo - it's not only martial arts, it's a Japanese cultural tradition and a philosophy of life. Forum Akademickie. 2017. https://forumakademickie.pl/news/budo-to-nie-tylko-sztuki-walki-to-japonska-tradycja-kulturowa-ifilozofia-zycia (accessed 2017 Sep 14)

8. Cynarski WJ. Scientific travel to Osaka: the next case study of martial arts tourism. Ido Movement for Culture. Journal of Martial Arts Anthropology 2018; 18(1): 23-30. doi: 10.14589/ido.18.1.4.

9. Cynarski WJ. Russian centre on the map of the martial arts tourism - Congress and festival in Saint Petersburg, Russia. Revista de Artes Marciales Asiaticas 2018; 13(1): 61-66

10. Krippendorf K. Content Analysis: An Introduction to Its Methodology. Thousand Oaks, CA: Sage; 2004

11. Skinner J, Edwards A, Corbett B. Research methods for sport management. London-New York: Routledge; 2014

12. Richards G, Munsters W, editors. Cultural Tourism Research Methods. Oxfordshire - Cambridge, MA: CABI; 2010

13. Kubala K. Budo to japońska tradycja kulturowa i filozofia życia / Budo is a Japanese cultural tradition and a philosophy of life. Gazeta Uniwersytecka UR 2017b; 5: 54-55

14. JAB, 2017 International Budo Conference / Japanese Academy of Budo 50th Anniversary Conference. Abstracts, Kansai University, Osaka, September 6-8, 2017, Abstract Book

15. Swider P. Rzeszowianie na Sympozjum Taekwondo w Korei / Rzeszow at the Taekwondo Symposium in Korea. Gazeta Uniwersytecka UR 2017; 4: 47

16. Su X. Reconstruction of tradition, modernity, tourism and Shaolin martial arts in the Shaolin Scenic Area, China. International Journal of the History of Sport 2016; 33(9): 934-950. https://doi.org/10.1080/09523367.2016.1227792

17. Cynarski WJ, Świder P. The journey to the cradle of martial arts: a case study of martial arts' tourism. Ido Movement for Culture. Journal of Martial Arts Anthropology 2017; 17(2): 24-33. doi: 10.14589/ido.17.2.3.

18. Hung Kam, Yang Xiaotao, Wassler Philipp, Wang Dan, Lin Pearl, Liu Zhaoping. Contesting the Commercialization and Sanctity of Religious Tourism in the Shaolin Monastery, China. International Journal of Tourism Research 2017; 19(2): 145-159. Version of Record online: 25 OCT 2016. https://doi.org/10.1002/jtr.2093

19. Griffith LM. Beyond Martial Arts Tourism: Outcomes of Capoeiristas' Apprenticeship Pilgrimages. Ido Movement for Culture. Journal of Martial Arts Anthropology 2016; 16(2): 32-40. doi: 10.14589/ido.16.2.4.

20. Cynarski WJ. A cyclical meeting of experts as a special case of martial arts tourism. Ido Movement for Culture. Journal of Martial Arts Anthropology 2017; 17(3): 31-37. doi: 10.14589/ido.17.3.4.

21. Cynarski WJ. Tourism of martial arts as sport tourism, on example from judo and jujutsu. Scientific Review of Physical Culture 2017; 7(2): 50-55

22. Slocum SL, Kline C, Holden A, editors. Scientific tourism: Researchers as Travellers; Routlege; 2015 